\title{
Induction and Morpho-Ultrastructural Analysis of Organogenic Calli of a Wild Passionfruit
}

\author{
Milene Alves de Figueiredo Carvalho ${ }^{1 *}$, Renato Paiva ${ }^{2}$, Vanessa Cristina Stein ${ }^{3}$, Raírys \\ Cravo Herrera ${ }^{4}$, Jorge Marcelo Padovani Porto ${ }^{5}$, Daiane Peixoto Vargas $^{6}$ and Eduardo \\ Alves $^{7}$ \\ ${ }^{1}$ Embrapa Café; Brasília - DF - Brasil. ${ }^{2}$ Departamento de Biologia; Setor de Fisiologia Vegetal; Universidade \\ Federal de Lavras, Lavras - MG - Brasil. ${ }^{3}$ Universidade Federal de Goiás; Jataí - GO - Brasil. ${ }^{4}$ Universidade \\ Federal do Pará; Altamira - PA - Brasil. ${ }^{5}$ Instituto Federal do Espírito Santo; Nova Venécia - ES - Brasil. \\ ${ }^{6}$ Embrapa Clima Temperado; Pelotas - RS - Brasil. ${ }^{7}$ Departamento de Fitopatologia; Laboratório de Microscopia \\ Eletrônica e Análise Ultraestrutural; Universidade Federal de Lavras; Lavras - MG - Brasil
}

\begin{abstract}
This work studied a new protocol for organogenic calli induction and characterization of the morphology and ultrastructure of callogenesis in leaf explants of Passiflora gibertii N. E. Brown, a native passion fruit species from Brazil. Calli induction was performed in different growth conditions (light and dark), different MS medium salt concentrations (MS and MS half strength) and the presence or absence of coconut water. The leaf explants maintained in the dark were more responsive to bud formation. In order to reduce spending on in vitro culture, the most suitable induction medium for $\mathrm{P}$. gibertii organogenesis could, therefore be the MS half strength salt concentration medium maintained in the dark. The addition of coconut water to the culture medium was essential for both calli induction and bud formation. The morphological and ultrastructural features of the organogenic calli were isodiametric cells, characterized by an organized cellular system, nucleus with prominent nucleoli, presence of starch grains and dense cytoplasm rich in endoplasmic reticulum. The scanning electron microscopy demonstrated that buds were present on these calli.
\end{abstract}

Key words: Passifloraceae, callogenesis, electromicroscopy, optic microscope, tissue culture

\section{INTRODUCTION}

Brazil is the center of diversity for the Passifloraceae family. It hosts more than 150 native species, including some wild Passiflora species that are not commercially cultivated (Bernacci et al. 2008). Breeding programs may contribute to improving disease resistance in existing commercial cultivars. One native Brazilian species with considerable potential in this context is Passiflora gibertii N. E. Brown, a fast growing vine with attractive mauve/purple flowers, which is apparently resistant to several important passion fruit diseases such as premature death and other diseases caused by soil-borne pathogens (Junqueira et al. 2005).

In vitro culture of native Passiflora spp. is a key tool for the production of clones with enhanced resistance and other desirable traits. Numerous tissue culture studies in Passiflora have been conducted and regeneration by organogenesis has been successfully reported from a wide range of species (Fernando et al. 2007; Lombardi et al. 2007; Pinto et al. 2010; Silva et al. 2011; Anand et

*Author for correspondence: milene.carvalho@embrapa.br 
al. 2012). However, this is not the case for $P$. gibertii, where there have been limited studies on in vitro cultivation (Faria et al. 2006; Faria et al. 2007; Carvalho et al. 2013).

The cytokinin 6-benzylaminopurine (benzyladenine) (BA) is very effective at promoting multiplication in several species (LimaBrito et al. 2011; Sá et al. 2012), including Passiflora spp. such as $P$. cincinnata Mast. (Lombardi et al. 2007; Silva et al. 2011), P. suberosa L. (Garcia et al. 2011), P. edulis Sims (Silva et al. 2011) and P. alata Curtis (Pacheco et al. 2012). Coconut water contains substances that are essential for the growth and for regeneration of many species such as $P$. edulis $\mathrm{x} P$. edulis var flavicarpa (Hall et al. 2000), P. edulis (Fernando et al. 2007) and P. alata Curtis (Pacheco et al. 2012). It is used as a growth supplement in plant tissue culture and its chemical composition is rich in sugars, vitamins, minerals, amino acids and phytohormones such as cytokinins that stimulate the division of mature plant cells (Yong et al. 2009).

Histological, morphological and ultrastructural analyses can be performed to monitor the regeneration and to differentiate organogenesis (Fernando et al. 2007; Silva et al. 2011; Rocha et al. 2012) from somatic embryogenesis (Pinto et al. 2011). By characterizing the regeneration path, the best growth conditions can be established allowing the development of efficient protocols for the induction and production of plants. There are no reports of organogenic calli induction in $P$. gibertii in the literature. It would, therefore, be useful to provide a detailed account of the morphological and ultrastructural changes during in vitro organogenic callus induction to form the seedlings from this native passion fruit. In this context, the objective of this study was to establish a protocol for organogenic calli induction on leaf explants of $P$. gibertii and to characterize the morphology and ultrastructure of these calli.

\section{MATERIAL AND METHODS}

Seeds of $P$. gibertii (access CPAC MJ-22-01) were obtained from the Embrapa Cerrados (CPAC) germplasm collection, Planaltina, DF. They were germinated in Plantmax $\mathrm{HT}^{\circledR}$ and the parent plants were maintained in a growth room at $25 \pm 2^{\circ} \mathrm{C}$, photon irradiance of $43 \mu \mathrm{mol} \mathrm{m} \mathrm{s}^{-2}$ and subjected to a $16 \mathrm{~h}$ photoperiod. The plants were 52 and 109 days old for the first and second experiment, respectively. The leaves collected from mother plants were used as explants for the experiments. In a laminar growth chamber, the leaves were first decontaminated by immersion in sodium hypochlorite solution $(\mathrm{NaOCl})$ containing $0.5 \%$ active chlorine and Tween 20 (one drop per 100 $\mathrm{mL} \mathrm{NaOCl}$ ) for $10 \mathrm{~min}$ and then washed three times with sterilized distilled water. After decontamination, leaves were excised $\left( \pm 1 \mathrm{~cm}^{2}\right)$ and the surfaces of the explants were given small cuts with a scalpel to induce callogenesis. The explants were then inoculated through placing the abaxial surface in contact with the medium.

In the first experiment, different growth conditions (light and dark) and different MS (Murashige and Skoog 1962) medium salt concentrations (full and half MS strengths) were tested. The media were supplemented with $8.88 \mu \mathrm{m}$ BA, 3\% sucrose, $5 \%$ coconut water and $0.5 \%$ agar $\left(\mathrm{Vetec}^{\circledR}\right)$. The second experiment assessed the influence of presence or absence of $5 \%$ coconut water in the MS half strength medium salt concentration supplemented with $8.88 \mu \mathrm{m} \mathrm{BA}, 3 \%$ sucrose and $0.5 \%$ agar. To obtain the organogenic calli, explants with calli from both experiments, were transferred to MS half strength salt concentration medium, supplemented with $2.22 \mu \mathrm{m}$ BA, $3 \%$ sucrose and $0.5 \%$ agar. The organogenic calli were transferred to MSM medium (Monteiro et al. 2000a) with 3\% sucrose and $2.89 \mu \mathrm{m}$ gibberellic acid $\left(\mathrm{GA}_{3}\right)$. The $\mathrm{pH}$ for all the media was adjusted to $5.8 \pm 0.1$ before autoclaving at $120^{\circ} \mathrm{C}$ for $20 \mathrm{~min}$. After inoculation, the explants from the first experiment were maintained under dark or in growth room under $36 \mu \mathrm{mol} \mathrm{m} \mathrm{m}^{-2} \mathrm{~s}^{-1}$ irradiance with $16 \mathrm{~h}$ photoperiod (light), both at $25 \pm 2{ }^{\circ} \mathrm{C}$ for 30 days. For the second experiment, the explants were maintained under dark and for calli from both the experiments and for the organogenic calli, the explants were cultivated in the light, all of them for a period of 30 days each.

For statistical analysis, the calli were classified in the following ordinal categories: $0=$ no callus formation, $1=$ swollen explants, 2 = early callus formation, $3=50 \%$ of the explants covered by callus, $4=$ more than $50 \%$ of the explants covered by callus and $5=$ explants completely covered by callus. A completely randomized design was used, consisting of 12 replicates per treatment for the first experiment and 45 replicates per treatment for the second experiment. Each replicate consisted of one explants. Data were analyzed by spearman 
correlations and Kruskal-Wallis tests, performed in SAS (SAS Institute, 2004).

Morphological and ultrastructural analyses were performed on calli resulting from the first experiment, cultivated in the MS half strength medium salt concentration, supplemented with $8.88 \mu \mathrm{m} \mathrm{BA}, 3 \%$ sucrose, $5 \%$ coconut water and $0.5 \%$ agar, maintained 30 days on dark or light and calli from dark sub-cultured to a new medium (MS half strength salt concentration medium supplemented with $2.22 \mu \mathrm{m} \mathrm{BA}, 3 \%$ sucrose and $0.5 \%$ agar) and maintained for seven days in a growth room under $36 \mu \mathrm{mol} \mathrm{m} \mathrm{m}^{-2} \mathrm{~s}^{-1}$ irradiance, at $25 \pm 2^{\circ} \mathrm{C}$ and $16 \mathrm{~h}$ photoperiod. In order to analyze the calli under scanning and transmission electron microscopy, they were fixed in modified Karnovisky [glutaraldehyde (2.5\%) and paraformaldehyde $(2.5 \%)$ in cacodylate buffer, $\mathrm{pH}$ 7.2] at room temperature for at least $24 \mathrm{~h}$. The calli were then washed in $0.05 \mathrm{M}$ cacodylate buffer (three times every $10 \mathrm{~min}$ ) and subsequently fixed in a solution containing $1 \%$ osmium tetroxide and $0.05 \mathrm{M}$ cacodylate buffer for $4 \mathrm{~h}$. The calli were then dehydrated in an ascending acetone gradient $(25,50,75$ and $90 \%)$ for $10 \mathrm{~min}$ and three times (10 min each) in $100 \%$ acetone.

Transmission Electron Microscopy (TEM) analysis was performed immediately after dehydration The calli were put in an ascending gradient acetone/Spurr resin 30\% for $8 \mathrm{~h}, 70 \%$ for $12 \mathrm{~h}$ and finally twice at $100 \%$ with a $24 \mathrm{~h}$ interval. To polymerize, the tissues were molded in pure silicon resin and dried in a forced-air oven at $70^{\circ} \mathrm{C}$ for $48 \mathrm{~h}$. The blocks obtained were subjected to thinning, using a razor blade to section the excessive resin. Subsequently, the blocks were cut into semi-thin $(1 \mu \mathrm{m})$ and ultrathin $(<100 \mathrm{~nm})$ sections by using a Reichert-Jung (ultra-cut) ultra-microtome, with a diamond blade.
The semi-thin sections were collected with a gold ring and put on glass slides and were later stained with toluidine blue $(1.0 \mathrm{~g}$ toluidine blue, $1.0 \mathrm{~g}$ sodium borate and $100 \mathrm{~mL}$ water purified in Millipore $0.2 \mu \mathrm{m}$ filter) and permanently mounted in Permoult medium. The ultra-thin sections were collected on formar-coated slot grids (Rowley and Moran 1975). These sections were post-stained with uranyl acetate, followed by lead acetate for 3 min and later examined in a Zeiss transmission electron microscope (EM 902 to 80Kv model).

For Scanning Electron Microscopy (SEM) analysis, after dehydration, the calli were dried in a critical point dryer CPD 030 using liquid $\mathrm{CO}_{2}$. The samples were then sputtered with gold prior to SEM analysis. Observations were made by using an electron microscope (LEO Evo 040) operating between 10 and $20 \mathrm{kV}$.

\section{RESULTS AND DISCUSSION}

There was no statistical difference in calli induction between the different concentrations of MS medium under different environmental conditions (light and dark), with average score of 0.5 . When calli explants were transferred to the MS half strength salt concentration medium, supplemented with BA $(2.22 \mu \mathrm{m})$ and maintained in a growth room under light, only a few explants formed in the dark showed buds after 30 days. After this period, the calli were transferred to MSM culture medium with $2.89 \mu \mathrm{m} \mathrm{GA}_{3}$ and maintained in a growth room under light. Several replicates from the calli originated from dark and sub-cultured to this new medium presented buds (Fig. 1A), while the calli cultured in the light showed brown color and only one replicate from this calli produced the buds (Fig. 1B).
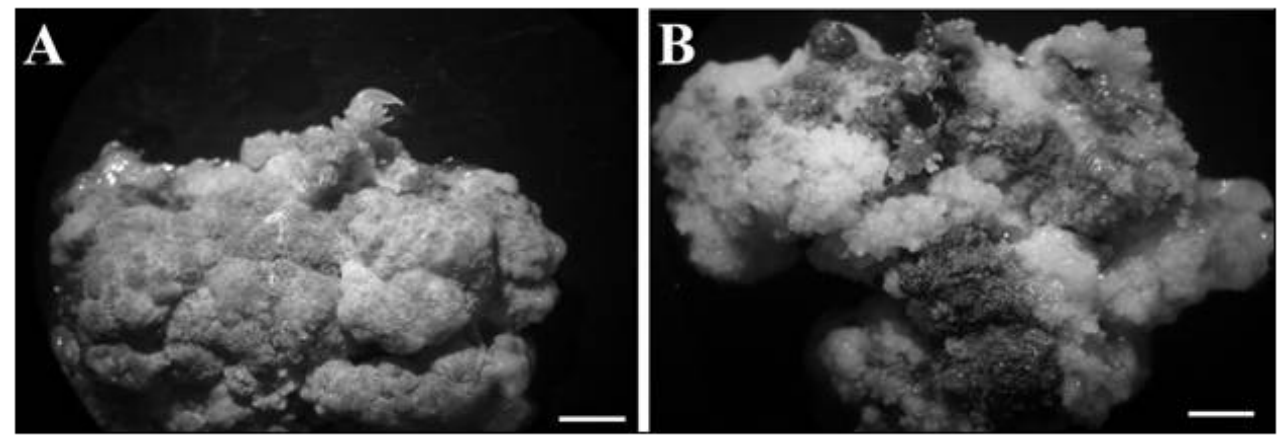

Figure 1 - Organogenic calli obtained from Passiflora gibertii leaf segments from dark (A) and light (B). $\mathrm{Bar}=3 \mathrm{~mm}(\mathrm{~A}, \mathrm{~B})$. 
Monteiro et al. (2000b) also observed bud formation when they cultured leaves of $P$. suberosa in vitro in MS medium in the dark at 26 $\pm 2^{\circ} \mathrm{C}$ for four weeks and then transferred calli with organogenic aspects to MSM medium with $2.89 \mu \mathrm{m} \mathrm{GA}_{3}$ under light. However, when tissues of $P$. suberosa were incubated in the dark without a subsequent period in the light, no significant shoot formation occurred (Garcia et al. 2011).

The browning in calli occurs mainly due to the oxidation of phenolic compounds by phenol oxidase (Erland and Mahmoud 2014) and it is likely that the products of this oxidation process are formed in the light (Afshari et al. 2011; Ndakidemi et al. 2014). Phenolic secretions and other exudates in plant tissue culture systems lessen explant initiation, growth and development (Ndakidemi et al. 2014; Yildirim and Turker 2014). The light source also causes an increase in lipid peroxidation leading to lower rates of physiological processes (Tariq et al. 2014; Yildirim and Turker 2014) as observed in the present work with $P$. gibertii calli cultured in the light.

The use of coconut water to the culture medium significantly influenced calli induction. Higher levels of calli induction were observed using coconut water (score of 0.72) compared with the absence of coconut water (score 0.28) (Fig. 2). The calli from the medium with coconut water presented clear bud formation (Fig. 3A), while calli from the medium without coconut water did not produce buds (Fig. 3B) after 30 days transferred to a new medium and maintained in the light.

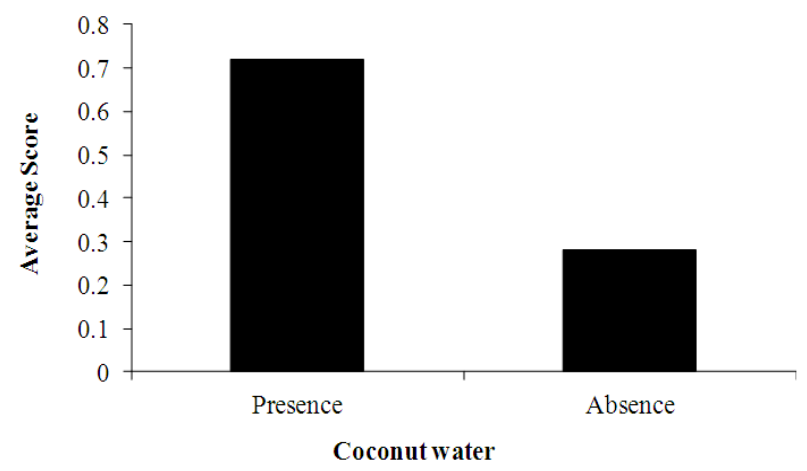

Figure 2 - Callus induction in Passiflora gibertii leaf segments in the presence and absence of coconut water in a MS half strength salt concentration medium with BA $(8.88 \mu \mathrm{m})$ at 30 days of cultivation.
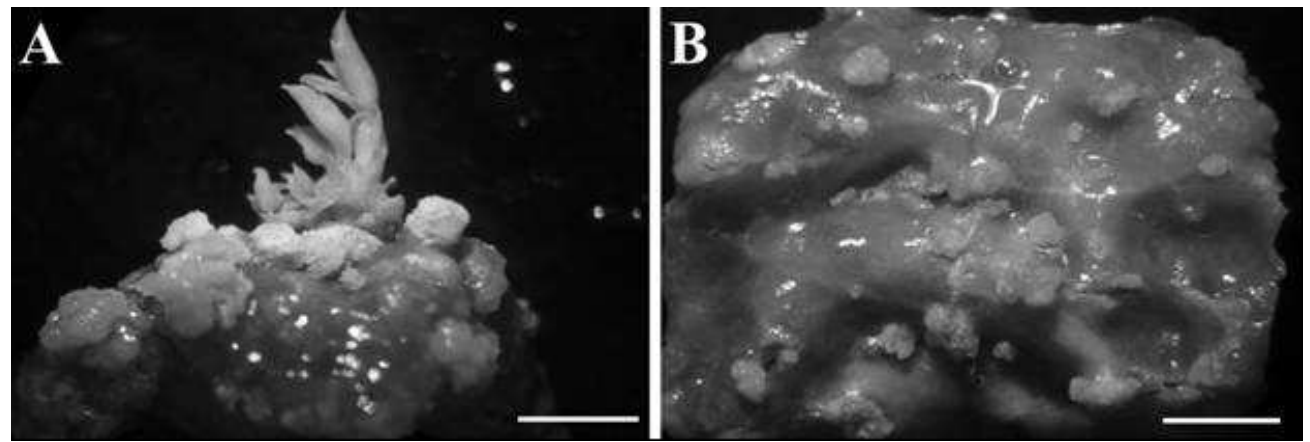

Figure 3 - Organogenic calli obtained from Passiflora gibertii leaf segments grown in culture medium with (A) and without (B) coconut water. $\mathrm{Bar}=3 \mathrm{~mm}(\mathrm{~A}, \mathrm{~B})$.

These results were in general agreement with several studies (Hall et al. 2000; Pacheco et al. 2012), indicating that coconut water and BA added to the culture medium of Passiflora spp. promoted the organogenesis. Kantharajah and Dodd (1990) reported that the addition of $20 \%$ coconut water to MS medium with BA $8.88 \mu \mathrm{m}$ significantly increased bud production of $P$. edulis var. Norfolk Island. Similarly, Fernando et al. (2007) reported that the direct organogenesis from leaf discs of $P$. edulis occurred only when leaf explants were cultured on MS medium supplemented with 4.44 $\mu \mathrm{m} \mathrm{BA}$ and $5 \%$ of coconut water. Coconut water may also be beneficial for the in vitro cultivation of other species. For example, Al-Khayri et al. (1992) observed that the addition of $15 \%$ coconut water to the culture medium increased callus growth, regenerative potential and bud growth in spinach (Spinacia oleracea L.).

The composition of coconut water, the liquid endosperm of coconut (Cocos nucifera L.), depends on factors such as the coconut variety, stage of maturity and cultivation practices (Prades et al. 2012). Coconut water presents a unique 
chemical composition of sugars, vitamins, minerals, proteins, amino acids and phytohormones and it is extensively used as a growth-promoting supplement in plant tissue culture (Ma et al. 2008; Yong et al. 2009). Coconut water, contains zeatin cytokinin, normally used to induce plantlet regeneration from the callus in plant tissue culture by stimulating the division of mature plant cells (Yong et al. 2009). It also contains indole-3-acetic acid auxin (Ma et al. 2008) that has the function of patterned differentiation of cells in meristems and immature organs (Uphade et al. 2008) and the vitamin C, which prevents the oxidation and protects the calli and shoot tissues and vitamins that are water- soluble and are required as coenzymes for enzymatic reactions essential for cellular function (Ma et al. 2008; Prades et al. 2012). The above could explain the organogenic calli obtained in the present study.

Morphological and ultrastructural differences were observed among the cells from different calli. Calli grown on the medium with BA and maintained in the light were characterized by the cells with both isodiametric (Fig. 4A) and elongated shape (Fig. 4B). In contrast, calli cultured on the medium with BA and maintained in the dark showed wellorganized cell proliferation with an isodiametric structure (Fig. 4C).
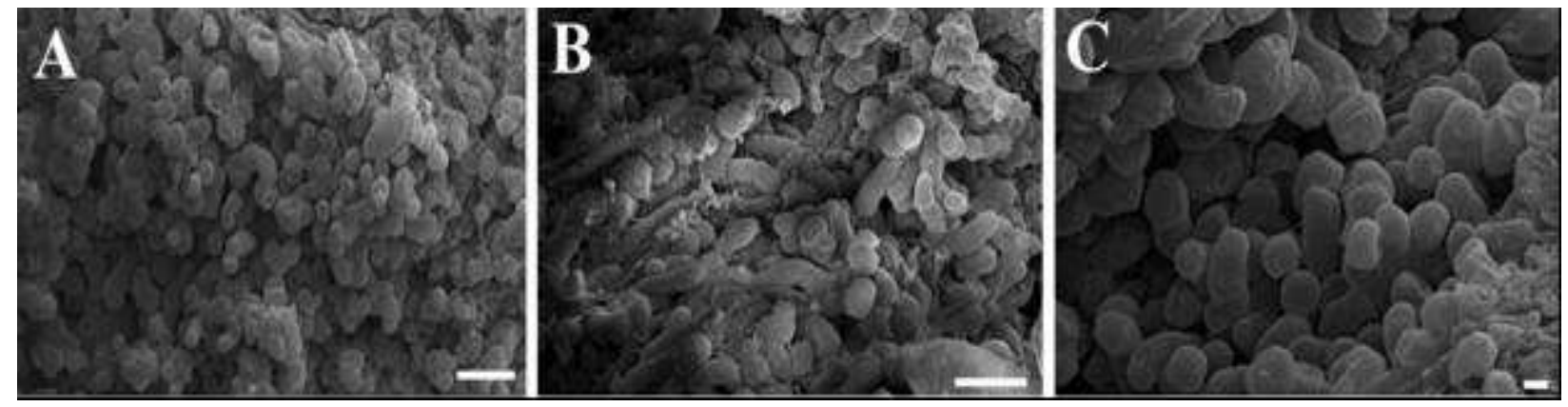

Figure 4 - Scanning electron micrographs of Passiflora gibertii calli grown in MS half strength salt concentrations medium with $\mathrm{BA}$, and maintained in the light $(\mathrm{A}, \mathrm{B})$ and in the dark $(\mathrm{C})$. Bars $=100 \mu \mathrm{m}(\mathrm{A}, \mathrm{B}), 20 \mu \mathrm{m}(\mathrm{C})$.

Studies using light microscopy (LM) and transmission electron microscopy (TEM) indicated that calli cells were dividing in an organized system in the calli cultured in the light (Fig. 5A and B) and in the dark (Fig. 6A and B). These calli also showed some common characteristics: a nucleus with prominent nucleoli (Figs. 5C and 6C), granular vacuole (Figs. 5D and $\mathrm{F}$ and $6 \mathrm{C}$ and D), dense cytoplasm rich in endoplasmic reticulum (Figs. 5C and D and 6C and F), starch grains (Figs. $5 \mathrm{~B}$ and $5 \mathrm{~F}$ and $6 \mathrm{~B}$ and $\mathrm{D}$ ), lipid bodies (Figs. 5D and $\mathrm{F}$ and $6 \mathrm{~F}$ ) and phenolic compounds (Figs. 5A and $\mathrm{B}$ and $6 \mathrm{~A}, \mathrm{~B}$ and $\mathrm{E})$. However, calli cultured in the light also had a cytoplasm rich in mitochondria and immature chloroplasts (Figs. 5C and E).

Deposition of phenolic compounds, such as tannins on calli cultivated in the light and on the dark is mainly found in the plant vacuoles (Parham and Kaustinen 1977) where they do not interfere with cellular metabolism unless an injury or cellular death happen. Knowledge of the biochemical makeup of the Passiflora genus comes from mainly studies on $P$. incarnata, $P$. edulis and $P$. alata and phytochemical studies are generally scarce for this genus (Costa and Tupinambá 2005). The chemical groups most frequently reported are indole alkaloids, flavonoids, sterols, lignans and cyanoglucosides. Since there has been reports on the presence of phenols for the Passiflora genus and tannins are polyphenols, there could be a possibility that this metabolite was also present in $P$. gibertii.

The ultrastructural cell characteristics observed in the present study have also been reported by other authors. Meristemoids cells in $P$. edulis (Rocha et al. 2012) and Bauhinia forficata and Glycine max (Appezzato-da-Glória and Machado 2004) presented dense cytoplasm, numerous mitochondria, prominent nuclei, concentrically arranged rough endoplasmic reticulum and plastids containing starch grains. 

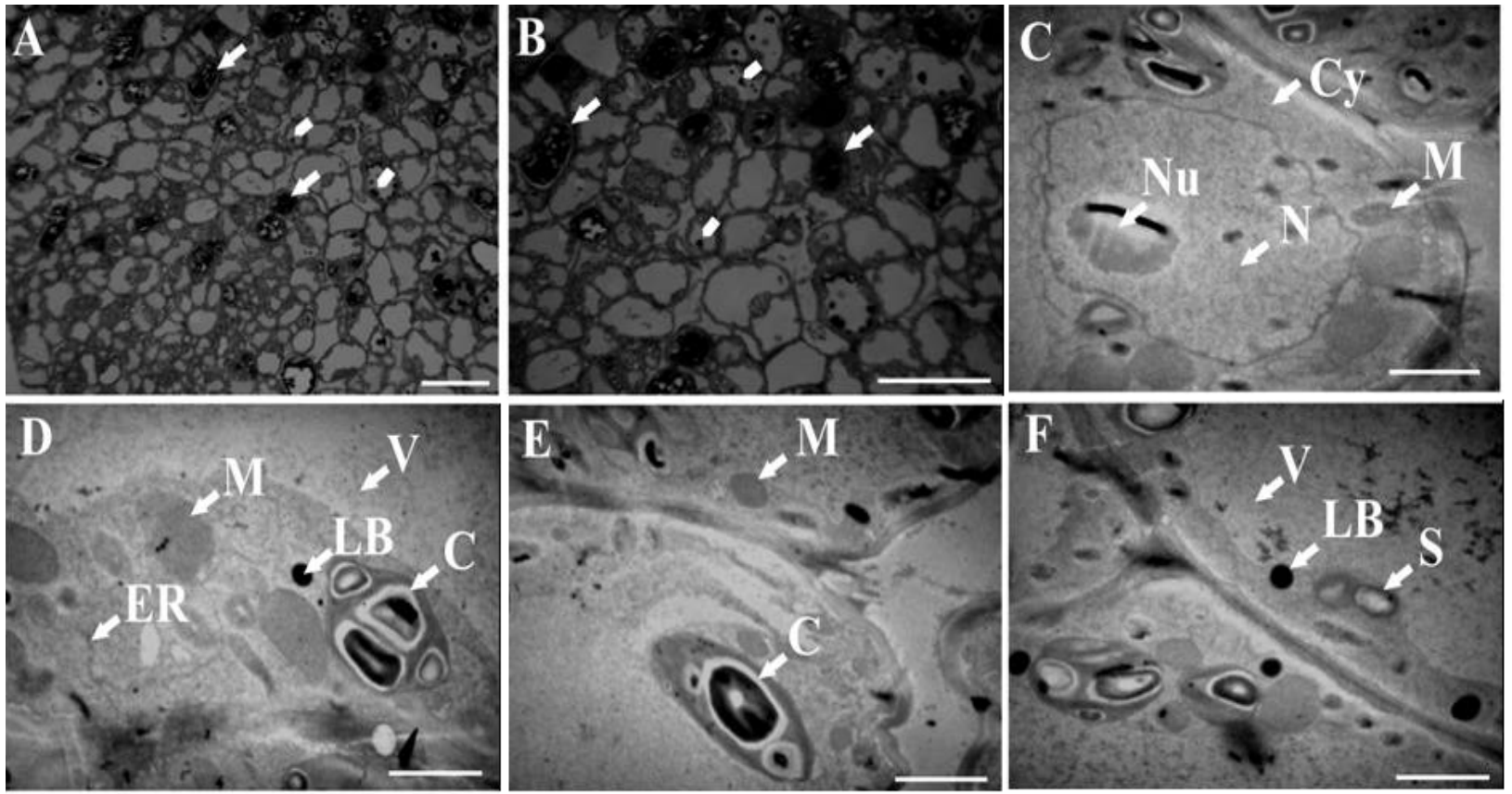

Figure 5 - Photomicrographs (A-B) and transmission electron micrographs (C-F) of Passiflora gibertii callus cells grown in a MS half strength salt concentrations medium with BA and maintained in the light. $\mathrm{M}=$ mitochondria, $\mathrm{ER}=$ endoplasmic reticulum, $\mathrm{Cy}=$ cytoplasm, $\mathrm{V}=$ vacuole, $\mathrm{LB}=$ lipid bodies, $\mathrm{S}=$ starch, $\mathrm{N}=$ nucleus, $\mathrm{Nu}=$ nucleolus, $\mathrm{C}=$ chloroplast. In $\mathrm{A}$ and $\mathrm{B}$, cells with phenolic compound accumulation $=$ arrows, starch grains $=$ arrowheads. Bars $=50 \mu \mathrm{m}(\mathrm{A}, \mathrm{B}), 2 \mu \mathrm{m}(\mathrm{C}, \mathrm{D}, \mathrm{E}, \mathrm{F})$.
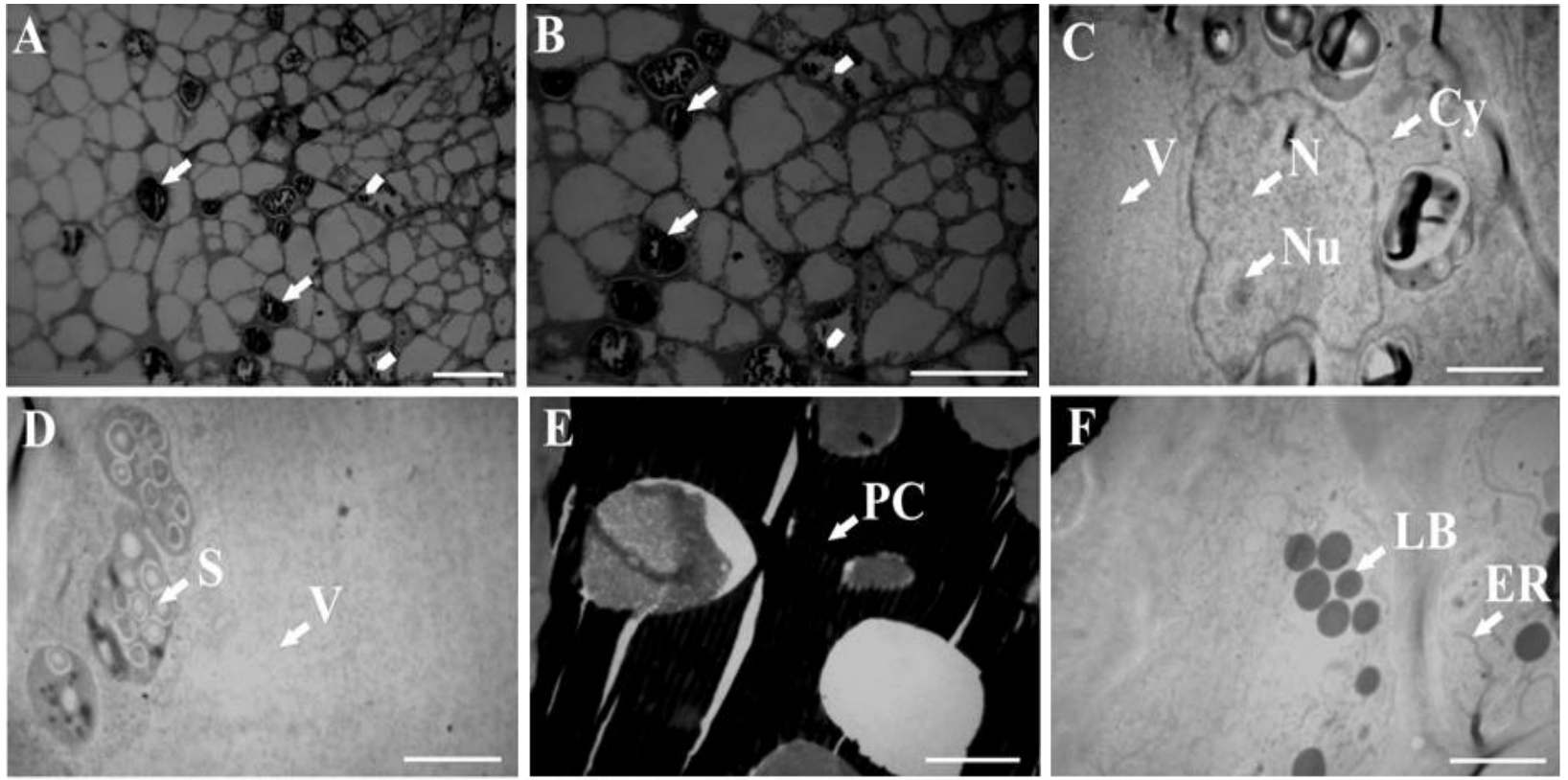

Figure 6 - Photomicrographs (A-B) and transmission electron micrographs (C-F) of Passiflora gibertii callus cells grown in a MS half strength salt concentrations medium with BA and maintained in the dark. $\mathrm{ER}=$ endoplasmic reticulum, $\mathrm{Cy}=$ cytoplasm, $\mathrm{V}=$ vacuole, $\mathrm{LB}=$ lipid bodies, $\mathrm{S}=$ starch, $\mathrm{N}=$ nucleus, $\mathrm{Nu}=$ nucleolus, $\mathrm{PC}=$ phenolic compounds. In $\mathrm{A}$ and $\mathrm{B}$, cells with phenolic compound accumulation = arrows, starch grains = arrowheads. Bars $=50 \mu \mathrm{m}(\mathrm{A}, \mathrm{B}), 2 \mu \mathrm{m}(\mathrm{C}, \mathrm{D}, \mathrm{E}, \mathrm{F})$. 
The meristemoids of B. forficata and G. max did not originate from typical meristemoids cells, but rather from highly vacuolated cells (Appezzato-daGlória and Machado 2004). Similar results were observed in the present study where cells with organogenic potential (Fig. 7A) were highly vacuolated with cytoplasm rich in organelles and starch grains (Figs. 5 and 6). These calli cells, formed in the dark and subsequently transferred to a MS half strength salt concentrations medium with $2.22 \mu \mathrm{m}$ BA maintained in the light, became organogenic (Fig. 7A), forming buds and foliar primordia after seven days (Fig. 7) in a new medium. The SEM results demonstrated morphological characterization of shoot buds based on emergence of the foliar primordia from a common axis (Figs. 7B, C and D) and not direct insertion of the base into the explants (isolated leaf structures).
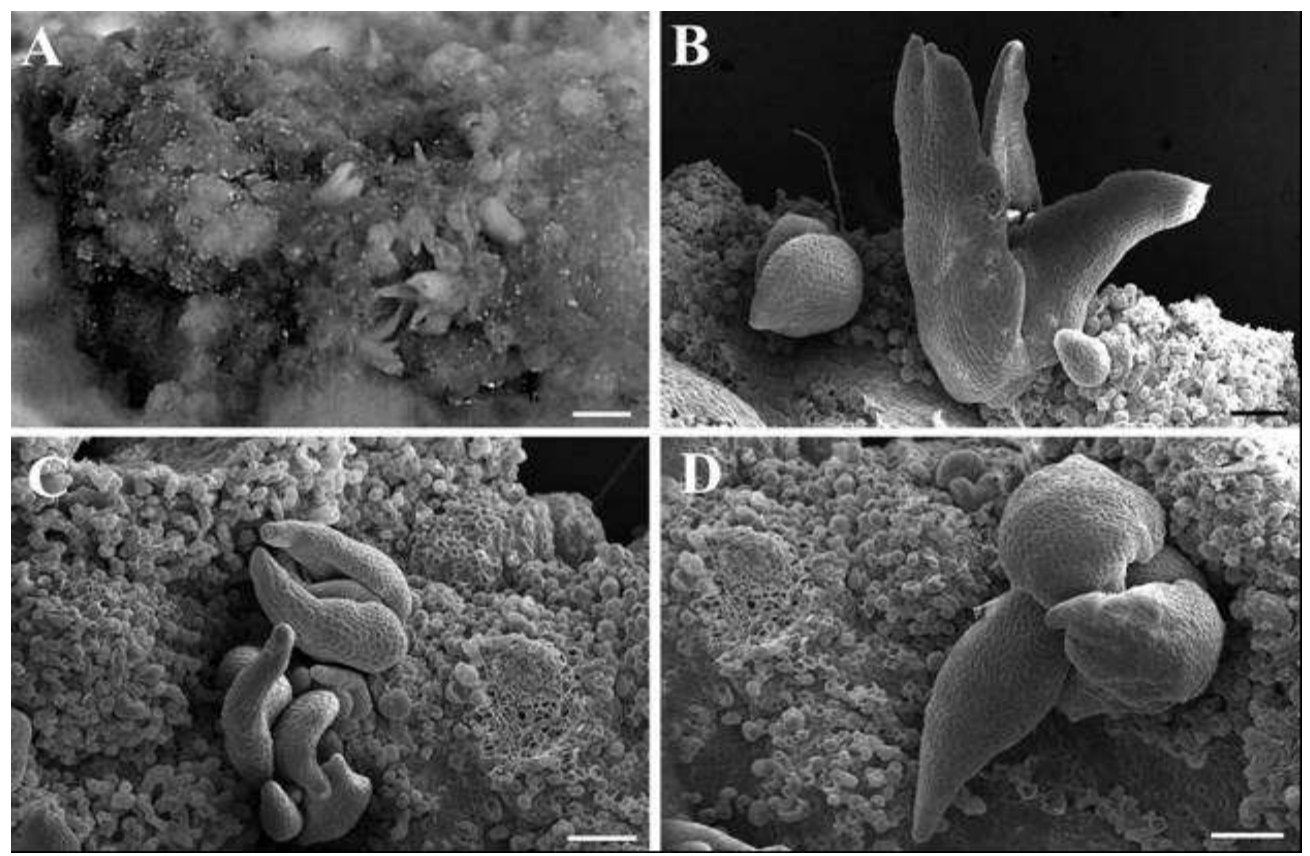

Figure 7 - Organogenic calli obtained from leaves of Passiflora gibertii grown in MS half strength salt concentrations medium with BA and maintained in the dark and seven days after transferring to new medium in the light. General aspect (A), scanning electron micrographs (B-D). Bars $=2 \mathrm{~mm}(\mathrm{~A}), 200 \mu \mathrm{m}(\mathrm{B}, \mathrm{C}, \mathrm{D})$.

Appezzato-da-Glória et al. (2005) described SEM observations of in vitro structures that were essential for quick morphological characterization, allowing the distinction between bud and leaf primordia. According to these authors, in Passiflora, the formation of leaf structures was frequently misinterpreted as buds that did not elongate. Structural analysis of the in vitro organogenesis in P. edulis f. flavicarpa Deg. and $P$. cincinnata Mast. demonstrated the strong tendency of explants to form leaf primordial that was not observed in the present work. Apparently this organogenic path compromises the success of in vitro culture, because the presence of the shoot apical meristem is essential for shoot production.

\section{CONCLUSIONS}

Passiflora gibertii calli produced in the dark were more responsive to bud formation. In order to reduce the spending on in vitro culture, the most suitable induction medium for $P$. gibertii organogenesis could, therefore, be the MS half strength salt concentration medium maintained in the dark. However, the addition of coconut water to the culture medium was essential for both callus induction and bud formation.

The morphological and ultrastructural features of the calli with organogenic potential were isodiametric cells, organized cellular system, nucleus with prominent nucleoli, presence of 
starch grains and dense cytoplasm rich in endoplasmic reticulum. The scanning electron microscopy demonstrated that the buds were present on these calli.

\section{ACKNOWLEDGEMENTS}

This work was financially supported by the following Brazilian agencies: Fundação de Amparo à Pesquisa do Estado de Minas Gerais (FAPEMIG), Coordenação de Aperfeiçoamento de Pessoal de Nível Superior (CAPES) and Conselho Nacional de Desenvolvimento Científico e Tecnológico (CNPq).

\section{REFERENCES}

Afshari RT, Angoshtari R, Kalantari S. Effects of light and different plant growth regulators on induction of callus growth in rapeseed (Brassica napus L.) genotypes. Plant Omics J. 2011; 4(2): 60-67.

Al-Khayri JM, Huang FH, Morelock TE, Busharar TA. Spinach tissue culture improved with coconut water. Hort Science. 1992; 27(4): 357-358.

Anand SP, Jayakumar E, Jeyachandran R, Nandagobalan V, Doss A. Direct organogenesis of Passiflora foetida L. through nodal explants. Plant Tissue Cult \& Biotech. 2012; 22(1): 87-91.

Appezzato-da-Glória B, Fernando JA, Machado SR, Vieira MLC. Estudos morfológicos, anatômicos, histoquímicos e ultra-estruturais da organogênese in vitro do maracujazeiro. In: Faleiro FG, Junqueira NTV, Braga MF, editors. Maracujá: germoplasma e melhoramento genético. Planaltina: Embrapa Cerrados; 2005. p. 382-407.

Appezzato-da-Glória B, Machado SR. Ultrastructural analysis of in vitro direct and indirect organogenesis. Rev Bras Bot. 2004; 27(3): 429-437.

Bernacci LC, Soares-Scott MD, Junqueira NTV, Passos IRS, Meletti LMM. Passiflora edulis Sims: the correct taxonomic way to cite the yellow passion fruit (and of others colors). Rev Bras Frutic. 2008; 30(2): 566-576.

Carvalho MAF, Paiva R, Alves E, Nogueira RC, Stein VC, Castro EM, et al. Morphogenetic potential of native passion fruit (Passiflora gibertii N. E. Brown.) calli. Braz J Bot. 2013; 36(2): 141-151.

Costa AM, Tupinambá DD. O maracujá e suas propriedades medicinais: estado da arte. In: Faleiro FG, Junqueira NTV, Braga MF, editors. Maracujá: germoplasma e melhoramento genético. Planaltina: Embrapa Cerrados; 2005. p. 474-506.
Erland LAE, Mahmoud SS. An efficient method for regeneration of lavandin (Lavandula $\mathrm{x}$ intermedia cv. 'Grosso'). In vitro Cell Dev Biol Plant. In Press. 2014. DOI: 10.1007/s11627-014-9614-4.

Faria GA, Costa MAPC, Junghans TG, Ledo CAS, Souza AS. Efeito da sacarose e sorbitol na conservação in vitro de Passiflora giberti N. E. Brown. Rev Bras Frutic. 2006; 28(2): 267-270.

Faria GA, Costa MAPC, Ledo CAS, Junghans TG, Souza AS, Cunha MAP. Meio de cultura e tipo de explante no estabelecimento in vitro de espécies de maracujazeiro. Bragantia. 2007; 66(4): 535-543.

Fernando JA, Vieira MLC, Machado SR, Appezzatoda-Glória B. New insights into the in vitro organogenesis process: the case of Passiflora. Plant Cell Tiss Org. 2007; 91(1): 37-44.

Garcia R, Pacheco G, Falcão E, Borges G, Mansur E. Influence of type of explant, plant growth regulators, salt composition of basal medium, and light on callogenesis and regeneration in Passiflora suberosa L. (Passifloraceae). Plant Cell Tiss Org. 2011; 106(1): 47-54.

Hall RM, Drew RA, Higgins CM, Dietzgen RG. Efficient organogenesis of an Australian passionfruit hybrid (Passiflora edulis x Passiflora edulis var flavicarpa) suitable for gene delivery. Aust J Bot. 2000; 48(5): 673-680.

Junqueira NTV, Braga MF, Faleiro FG, Peixoto JR, Bernacci LC. Potential of wild species of passionfruit as sources of resistance to diseases. In: Faleiro FG, Junqueira NTV, Braga MF, editors. Passionfruit: germplasm and breeding. Planaltina: Embrapa Cerrados; 2005. p. 143-148.

Kantharajah AS, Dodd WA. In vitro micropropagation of Passiflora edulis (purple passionfruit). Ann Bot. 1990; 65(3): 337-339.

Lima-Brito A, Resende SV, Lima COC, Alvim BM, Carneiro CE, Santana JRF. In vitro morphogenesis of Syngonanthus mucugensis Giul. subsp. mucugensis. Ciênc Agrotec. 2011; 35(3): 502-510.

Lombardi SP, Passos IRS, Nogueira MCS, Appezzatoda-Glória B. In vitro shoot regeneration from roots and leaf discs of Passiflora cincinnata Mast. Braz Arch Biol Technol. 2007; 50(2): 239-247.

Ma Z, Ge L, Lee ASY, Yong JWH, Tan SN, Ong ES. Simultaneous analysis of different classes of phytohormones in coconut (Cocos nucifera L.) water using high-performance liquid chromatography and liquid chromatography-tandem mass spectrometry after solid-phase extraction. Anal Chim Acta. 2008; 610(2): 274-281.

Monteiro ACBA, Higashi EN, Gonçalves AN, Rodriguez APM. A novel approach for the definition of the inorganic medium components for micropropagation of yellow passionfruit (Passiflora edulis Sims. f. flavicarpa Deg.). In vitro Cell Dev Biol Plant. 2000a; 36(6): 527-531. 
Monteiro ACBA, Nakazawa GT, Mendes BMJ, Rodriguez APM. Regeneração in vitro de Passiflora suberosa a partir de discos foliares. Sci Agric. 2000b; 57(3): 571-573.

Murashige T, Skoog F. A revised medium for rapid growth and bioassays with tobacco tissue cultures. Physiol Plantarum. 1962; 15(3): 473-497.

Ndakidemi CF, Mneney E, Ndakidemi PA. Effects of ascorbic acid in controlling lethal browning in in vitro culture of Brahylaena huillensis using nodal segments. Am J Plant Sci. 2014; 5(1): 187-191.

Pacheco G, Garcia R, Lugato D, Vianna M, Mansur E. Plant regeneration, callus induction and establishment of cell suspension cultures of Passiflora alata Curtis. Sci Hortic. 2012; 144: 42-47.

Parham RA, Kaustinen HM. On the site of tannin synthesis in plant cells. Bot Gaz. 1977; 138(4): 465467.

Pinto APC, Monteiro-Hara ACBA, Stipp LCL, Mendes BMJ. In vitro organogenesis of Passiflora alata. In vitro Cell Dev Biol Plant. 2010; 46(1): 28-33.

Pinto DLP, Almeida AMR, Rêgo MM, Silva ML, Oliveira EJ, Otoni WC. Somatic embryogenesis from mature zygotic embryos of commercial passionfruit (Passiflora edulis Sims) genotypes. Plant Cell Tiss Org. 2011; 107(3): 521-530.

Prades A, Dornier M, Diop N, Pain J-P. Coconut water uses, composition and properties: a review. Fruits. 2012; 67(2): 87-107.

Rocha DI, Vieira LM, Tanaka FAO, Silva LCS, Otoni WC. Anatomical and ultrastructural analyses of in vitro organogenesis from root explants of commercial passion fruit (Passiflora edulis Sims). Plant Cell Tiss Org. 2012; 111(1): 69-78.

Rowley CR, Moran DT. A simple procedure for mounting wring wrinkle - free sections on formvar coated slot grids. Ultramicrotomy. 1975; 1(1): 151155 .
Sá AJ, Lédo AS, Lédo CAS, Pasqual M, Silva AVC, Silva Junior JF. Sealing and explant types on the mangaba micropropagation. Ciênc Agrotec. 2012; 36(4): 406-414.

SAS Institute. SAS user's guide: statistic: version 9.1.3. Cary: SAS Institute; 2004.

Silva CV, Oliveira LS, Loriato VAP, Silva LC, Campos JMS, Viccini LF, et al. Organogenesis from root explants of commercial populations of Passiflora edulis Sims and a wild passionfruit species, $P$. cincinnata Masters. Plant Cell Tiss Org. 2011; 107(3): 407-416.

Tariq U, Ali M, Abbasi BH. Morphogenic and biochemical variations under different spectral lights in callus cultures of Artemisia absinthium L. $J$ Photoch Photobio B. 2014; 130(5): 264-271.

Uphade BK, Shelke SS, Thorat DG. Studies on some physico-chemical characteristics of coconut water near sugar and chemical factory, Kopergaon (M. S.). Int J Chem Sci. 2008; 6(4): 2052-2054.

Yildirim AB, Turker AU. Effects of regeneration enhancers on micropropagation of Fragaria vesca L. and phenolic content comparison of field-grown and in vitro-grown plant materials by liquid chromatography-electrospray tandem mass spectrometry (LC-ESI-MS/MS). Sci Hortic. 2014; 169: 169-178.

Yong JWH, Ge L, Ng YF, Tan SN. The chemical composition and biological properties of coconut (Cocos nucifera L.) water. Molecules. 2009; 14(12): 5144-5164. 